УДК: 811.163.41’35(091)

$811.163 .41(091)$

DOI: $10.18485 /$ belic_slv.2016.1.ch12

\title{
Бранкица Чигоја
}

\section{НЕКОЛИКО НАПОМЕНА О ТЕРМИНИМА ЗЕТСКО-ХУМСКИ И РАШКИ ПРАВОПИС}

Називе зетско-хумски/босански и рашки (старији и млађи) правопис увео је у нашу науку Александар Белић као називе за две правописне традиције којима се одликују најстарији сачувани српски ћирилски споменици. Он је то учинио у својој познатој студији Учешће Св. Саве и юегове школе у стварағу нове редакиије српских ћирилских споменика (Белић 1999: 357-396), у којој је анализирао правопис најстаријих сачуваних ћирилских споменика, као што су: Мирослављево јеванђеље, Карејски типик, Хиландарски типик и Хиландарска повель Стефана Првовенчаног. Сви ови споменици настали су на два различита места, која као шира подручја старе српске државе Белић именује по старим називима државе, зетско-хумски и рашки правопис. Белић, заправо, проблеме правописа Мирослављевог јеванђељь, нашег најстаријег споменика писаног црквеним и књижевним језиком српскословенским, посматра повезано са целокупном проблематиком стварања и развоја српске редакције. Он је, најпре, анализом правописа овог споменика уочио постојање двеју правописних традиција, једне - којом је писан главни текст и друге - којом се служио Глигорије Дијак при крају самог јеванђеља. Он даље констатује да је основни текст писан зетско-хумском редакцијом која је старија, и која се „сачувала неко време у Хуму, а знатно дуже у Босни" (Белић 1999: 365).

Та се зетско-хумска редакција, према Белићу, није дуго задржала у самом Хуму и Зети у непромењеном облику. Наиме, „чим се државни центар - за време Немањино - преселио у Рашку, добила је та азбука неке мале измене које се лепо могу пратити у Немањиној повељи Хиландару од 1199. године, али које су се, вероватно, и знатно раније налазиле у споменицима световног карактера" (Белић 1999: 365). Сви ти споменици са рашког подручја припадају једној школи писмености: Хиландарској или Савиној (Белић 1999: 367).

А. Белић, дакле, претпоставља да је старија правописна традиција она која је настала у Зети и Хуму. Млађи рашки правопис био би онај за 
чији настанак је заслужан Сава Немањић. У недостатку других чињеница, обе правописне традиције Белић доводи у везу са хипотезом о некадашњој широкој распрострањености глагољице. Он стога каже: „Мора се претпоставити да је некад у целој земљи нашој била у употреби глагољица" (Белић 1999: 365). Утицај глагољске ортографске праксе огледа се пре свега у зетско-хумском правопису, и то: ь $(=\mathbf{k}, \mathbf{z})$ Ћ $(=\hbar, \hbar)$, $\mathbf{k}(=\mathbf{k}$, $\boldsymbol{\boldsymbol { a }}), \boldsymbol{\epsilon}(=\mathbf{\kappa}, \mathbf{\epsilon})$ и $\boldsymbol{\boldsymbol { v }}$ (чија је употреба према $\boldsymbol{\gamma}$ постала нарочита). Ову правописну праксу Белић сматра старијом по свим наведеним цртама, а нарочито по употреби слова танко јер, чији начин писања доводи у везу са његовом изговорном вредношћу.

Познато је да је из прасловенског језика наш језик наследио два полугласника, који су се врло рано, још пре писаних споменика на нашем језику, изједначила у корист једнога, и то у већем делу у корист полугласника реда $a$, и у мањем делу говора у корист полугласника реда e. Старословенски језик имао је оба полугласника и стога старословенски споменици имају два знака: танко и дебело јер. Српска ћирилска писменост има само танко јер (до XIV века), а Белић поводом тога каже: „И тако полугласник ь као једини полугласник наш - знак је стварне промене старословенске азбуке у корист народног изговора. Та се промена могла само тамо извршити где се у то време полугласник тако изговарао; a то је била - Зета. Зато се и може рећи да је почетак ћирилске редакције наших споменика извршен у Зети која је први јачи политички центар наше државе. Та се редакција проширила доцније и на Хум и на Рашку. Можда су ти први почеци стварања наше азбуке извршени око краја XI века... зато у Мирослављевом јеванђељу, чији главни текст припада знатно старијем времену, нема већ никаква колебања између ъ и ь, већ се употребљава једино ь” (Белић 1999: 364).

Белић је, према томе, као место настанка српске редакције одредио Зету, а зетско-хумски правопис као старију фазу у развитку ћирилске правописне праксе. Та пракса проширила се, према Белићевом мишљењу, и на рашко подручје и то је пракса која је на том простору негована све до Саве Немањића и његовог одласка у манастир Хиландар. Најстарији споменици, као што су: Хиландарски типик, Карејски типик и Хитандарска повела Стефана Првовенчаног, изашли су из једне школе: из Хиландарске или Савине школе (Белић 1999: 367). Основна је црта Савине прераде Немањине ортографије - увођене г и к. Међутим, правопис којим се Свети Сава служио пре одласка на Свету гору имао је још увек $\mathbf{k}$ $=\mathrm{ja}$, али после боравка на Светој гори он редовно пише га $=$ ја и $к=$ је.

Осим Белићеве хипотезе о месту настанка српске редакције, у нашој науци изнете су и друге хипотезе. Такође оспоравана је и Белићева 
претпоставка о употреби танког јера као резултата изговорне вредности полугласника (реда $е$ ). Томе се противи чињеница да су „и на истоку постојале ортографске школе са једнојеровским правописом (уп. нпр. бугарски, Енински апостол из XI века), па је природно да су се на српскохрватском терену, где се већ пре писаних споменика изгубила изговорна разлика између два полугласа, радије усвајали такви преседани него двојеровски правопис, који у нашим областима није могао одржати свест о изговорној разлици два јера. Отуда је веома мало вероватна Белићева претпоставка да је избор танког јера био условљен отвореношћу изговара јаког полугласа у Зети. Вероватније је да су о томе одлучивали графички и технички разлози, а можда и случајност" (Родић/Јовановић 1986: 8).

Међутим, и поред често навођене претпоставке о избору танког јера као графички једноставнијег знака, ипак у нашој науци Белићева претпоставка о вези слова танко јер са његовом изговорном вредношћу није напуштена. У новије време на сличан начин, доводећи у везу писағе и изговор танког јера, изнео је у нашој науци своју хипотезу професор Александар Младеновић ослањајући се на резултате истраживања бугарског научника Ивана Галабова (Младеновић 2002: 59-63).

Професор Младеновић сматра да „употреба само једног знака за обележавање једног полугласника на месту старих двају полугласника - какав је случај у поменутим најстаријим сачуваним српским писаним споменицима с краја XII века (а, наравно, и касније) - значи да се у тим споменицима језик, којим су они писани, одликује само једним полугласником" (Младеновић 2002: 61). То је, наравно, истовремено одлика и правописа (односно графије) тих споменика (тзв. једнојеров правопис). Та правописна црта је, по мишљењу професора Младеновића, одраз једне црте фонолошког вокалског система народног (раз)говорног српског језика. То значи да се употребом једног знака (ь) на месту некадашњих двају полугласника тим истим знаком у неком старом споменику нису могла обележавати два полугласника из разлога што се не могу две различите фонеме (у овом случају полугласник предњег и полугласник задњег реда) означавати једним истим знаком (Младеновић 2002: 61).

Као пример професор Младеновић наводи у старословенском језику различит начин писања речи дьмь и съмъ који проистиче из различитог изговора полугласника. Међутим, у српским споменицима обе ове речи пишу се само са танким јер сьнь, дьнь, што значи да су се на исти начин и изговарале (само са једним полугласником). Како се изговарао полугласник у овим речима у нашим најстаријим писаним споменицима, можемо закључити на основу рефлекса полугласника у српском јези- 
ку. Професор Младеновић наводи и чињеницу да је негде од краја XIV века у српском народном језику извршена вокализација полугласника, тако да су се наведене речи од тада изговарале као: дан и сан (најчешће) и дён и сён (ретко, само на западу у зетским говорима Црне Горе). Наведени рефлекси, према мишљењу професора Младеновића, могу да значе да је поглугласник пре његове вокализације у српским споменицима с краја XII века био: или реда $a$ (најчешће) или реда $e$ (ретко). То изједначење полугласника у српским народним говорима могло се десити најкасније негде до краја десетог, односно до почетка једанаестог века код Срба, дијалекатски неједнако (Младеновић 2002: 61).

Са тим једним полугласником у вокалском фонолошком систему свог народног (раз)говорног језика „Срби су у својој средини могли 'дочекати' увођење словенског богослужења на старословенском језику (током X, односно до краја друге деценије XI века"). А тај старословенски језик који су Срби примили као свој црквени и књижевни језик (тада већ донекле измењен у односу на најстарије преводе Ћирила и Методија) тај језик је могао имати у себи или: а) два полугласника (ь, ъ) или б) један полугласник. У првом случају старословенске фонеме ь, ъ на српском језичком подручју биле су захваћене процесом србизирања - тако што су биле сведене на један полугласник јер је српски народни језик имао само један полугласник. Тај један полугласник се морао обележавати или са ъ или са ь јер је старословенски у српској средини усвајан преко књига са словенским богослужењем. За Србе је у том случају било свеједно, сматра професор Младеновић, да ли ће свој изговорни један полугласник у свом писању означити са ъ или ь. То је један од разлога зашто се у српској писмености један полугласник из српског народног (раз)говорног језика обележава са ь, од најстаријих времена.

Као други могући разлог, уверљивији од првог, професор Младеновић износи своју претпоставку засновану на истраживањима старих ћирилских бугарских споменика бугарског научника Ивана Галабова. Према истраживањима овог научника, старословенски језик којим су писане књиге са старословенским богослужењем, а са којима је ово богослужење „донесено” у српску језичку средину - могао је имати само један полугласник који се означавао словом ь (Младеновић 2002: 62).

Изнето гледиште поменути бугарски научник засновао је на епиграфском материјалу, на натписима у Округлој цркви у Преславу из времена Симеона, и то на речима које се пишу само са ь уместо и и ь (вь, wтьвь лабову, пише се само танко јер, зато што је у тадашњем бугарском црквеном и књижевном језику таква промена извршена (уместо ь, $\mathbf{z}=\mathbf{\mathbf { s }}$ ). 
Таква промена морала је имати ослонца у одговарајућем бугарском народном говору, дијалекту, у којем су се два полугласника изједначила у корист једног. А такав дијалекат могао је бити сличан неким данашњим бугарским народним говорима који уместо старих двају полугласника и назала задњега реда имају рефлексе: отворено $e$ (у слоговима под акцентом) и редуцирано $a$ (у неакцентованим слоговима) (Младеновић 2002: 62).

Изговорна разлика била је мала између бугарског $\ddot{e} / a(<\mathbf{\mathbf { b }}, \mathbf{\mathbf { s }})$ и српског једног полугласника реда a/e (<ь, ъ), што је омогућило код Срба измену дотадашње функције „преславског” ь да се овим словом почне означавати поменути српски полугласник. Може се претпоставити да је танко јер у српској писмености пореклом из „преславске” ћирилице. Танко јер се учврстило у српској ћирилици и наставило да се употребљава означавајући полугласник све негде до XIV века, када се у низу српских народних говора полугласник вокализовао у $а$ (ређе у ё), после чега је у српској писмености слово танко јер почело означавати самогласник $a$ (Младеновић 1997: 102).

Важна вокалска особина која је на фонолошком плану била заједничка језику Срба и Бугара - била је употреба једнога полугласника који се и обележавао знаком ь. Она на неки начин, „указује на међусобно заједништво црквеног и књижевног језика Срба и Бугара у поменутим далеким временима" (Младеновић 2002: 63).

Изнесена претпоставка професора Младеновића поново је скренула пажњу на чињеницу да изворе српске ћирилске писмености треба тражити на истоку и стога је његово тумачење ближе хипотезама које почетке стварања српске редакције виде у источнијим српским пределима. Да поменемо само неке од таквих хипотеза.

Ирена Грицкат претпоставља да је српска редакција старословенског језика настала „северно од Скопља” на „линији Тетово-СкопљеКратово”, да она није настала на српским теренима у нашем савременом схватању нити на хумском терену, него је потекла са „јужнијих граничних српскомакедонских" подручја (Грицкат 1975: 31). Такође, она сматра „да нема сасвим сигурних аргумената који би говорили против претпоставке о српској редакцији као приближној вршњакињи охридске и преславске школе", тј. да су за време владавине српског кнеза Часлава Клонимировића (927-950) постојали одређени друштвени услови, извесна политичка самосталност и постојање сопствене рашке епископије, који су могли ојачати тадашњу српску земљу, а што је све погодовало и развитку црквеног језика, старословенског типа, редигованог у духу српског народног језика (Грицкат 1975: 31-37). 
Сличног је мишљења и Ђорђе Сп. Радојчић, који истиче рано постојање књижевности на терену између Косова и планине Риле у Бугарској (Радојчић 1962: 13-16). У прилог претпоставци Ирене Грицкат иде и мишљење Петра Ђорђића, који истиче да се употреба ь у српској редакцији извршила „и под македонским утицајем” наводећи да је то „особина кратовске писарске школе” (Ђорђић 1987: 71-72).

Супротно А. Белићу, Олга Недељковић сматра да „рашка школа” није касније настала из „зетске”, већ да су обе настајале у исто време. Тако би српска редакција била истовремено појава са великог зетско-хумскобосанско-рашког простора, који О. Недељковић зове „штокавско-јадранско подручје” (Недељковић 1979: 177-188).

Ове претпоставке, изнесене независно једна од друге, све указују на то да писање ь не мора упућивати на Зету као на терен настанка ове редакције. Правопис најстаријих споменика несумњиво показује да је постојало извесно двојство у правописној пракси. „Створило се и трајније одржава извесно ортографско двојство наших источнијих и западнијих крајева, које је дошло до изражаја и у црквеним текстовима и повељама" (Родић/Јовановић 1986: 9). Западнији крајеви чували су конзервативније стање, добрим делом изван еволуције остала је босанска, дубровачка, донекле и хумска ћирилска пракса.

Ортографијом српскохрватских ћирилских повеља и писама XII и XIII века бавили су се Павле Ивић и Вера Јерковић. Они су утврдили извесне карактеристике у ортографији као рашку правописну праксу, а све остале споменике ставили су под одредницу запад: обично га (Рашка), запад $\mathbf{k}$; обично к (Рашка), обично є (запад); често га (иза меког консонанта, Рашка), скоро увек а (запад) и сл. (Ивић/Јерковић 1981: 218). Међутим, „сви сачувани зетски споменици сагласни су са рашким” (Родић/ Јовановић 1986: 9). То је још једна чињеница која би била добар разлог да се поново размисли о ваљаности термина зетско-хумски правопис, нарочито првог дела полусложенице (зетско).

Правопис наших најстаријих сачуваних ћирилских натписа из XII и XIII века такође потврђује постојање наведеног правописног двојства, и то конзервативнијег хумско-босанског подручја, док се зетско подручје не разликује од рашког у главној особини (употреба прејотованих вокала) (Чигоја 2003: 113). Поједини аутори који се баве правописом наших старих ћирилских споменика опрезније одређују ово правописно двојство. Тако, нпр., Вера Јерковић, наводећи правописне карактеристике неких споменика, те правописе означава као: а) норма глагољице (очито замењује Белићев термин зетско-хумски); б) „искључиво ћирилска особина” (очито Савин или млађи рашки правопис); в) ненормализовано писане прејото- 
ваних вокала (потврда ћирилско-глагољске симбиозе) - што би могло донекле одговарати Белићевом термину старији рашки правопис (Јерковић 1980: 23).

Из напред наведеног произлази да је „везивање различитих система и школа за одређене области (Зету, Хум, Рашку) врло условно и хипотетично” (Родић/Јовановић 1986: 12). У разним срединама поједини писари могли су стицати и различите навике зависно од учитеља и од текстова које су користили. Гордана Јовановић сматра да је дукљански период старосрпске државе био веома значајан за формирање старије, тзв. зетско-хумске ортографије, док је млађа, рашка ортографија уобличена тек у немањићком периоду (Родић/Јовановић 1986: 12).

Према томе, Белићев термин: зетско-хумски/босански правопис у нашој језичкој дисциплини ваљало би кориговати у босанско-хумски, док би термин рашки правопис несметано и даље могао задржати исту функцију. Оба термина треба врло условно схватити и не доводити их у везу са местом настанка српске редакције старословенског језика.

\section{ЛИТЕРАТУРА}

Белић 1999: Александар Белић, Историја српског језика, Изабрана дела Александра Белића, том 7, Београд: Завод за уџбенике и наставна средства.

Грицкат 1975: Ирена Грикцат, Студије из историје српскохрватског језика, Београд: Народна библиотека Србије.

Ђорђић ${ }^{2}$ 1987: Петар Ђорђић, Историја српске ћирилище, Београд: Завод за уџбенике и наставна средства.

Ивић/Јерковић, 1981: Павле Ивић, Вера Јерковић, Правопис српскохрватских ћирилских повеља и писама ХII и ХІІІ века, Нови Сад: Матица српска.

Јерковић 1980: Вера Јерковић, „Средњовековне ортографске школе код Срба”, Југостовенски семинар за стране слависте, 31, Београд, 19-28.

Младеновић 1977: Александар Младеновић, „Напомене о српскословенском језику”, Зборник за филологију и лингвистику, XX, 1-20.

Младеновић 1997: Александар Младеновић, „Српска редакција старословенског језика и употреба само танког јера у писању”, Зборник Матище српске за филологију и лингвистику, XL/1, 97-104.

Младеновић 2002: Александар Младеновић, „О једној заједничкој особини старог црквеног и књижевног језика код Срба и Бугара", Зборник Матице српске за филологију и лингвистику, XLV/1-2, 59-65. 
Недељковић 1979: Олга Недељковић, „Свети Сава и рашка правописна школа”, у: Међународни научни скуп Сава Нематьћ, 177-188.

Радојчић 1962: Ђорђе Сп. Радојчић, Развојни лук старе српске књижевности, Нови Сад: Матица српска.

Родић/Јовановић, 1986: Никола Родић, Гордана Јовановић, Мирослављево јеванђељье (критичко издағь), Београд: САНУ, Институт за српскохрватски језик.

Чигоја 2003: Бранкица Чигоја, Најстарији српски ћирилски натписи: графија, ортографбија и језик, Београд: Чигоја штампа.

\author{
Brankica Čigoja \\ A FEW REMARKS ON THE TERMS “ZETA-HUMSKA REGIONAL \\ ORTHOGRAPHY” AND "RASHKA REGIONAL ORTHOGRAPHY"
}

Summary

In this work, the author contemplates the origins and meanings of the terms which were used to symbolize two very old orthographic traditions of Serbian literacy; these are (both the order and the more recent): "Zeta-Humska/Bosnian regional orthography" and "Rashka regional orthography". 